\title{
sensors
}

ISSN 1424-8220

(C) 2002 by MDPI

http://www.mdpi.net/sensors

\section{Polystyrene Based Silver Selective Electrodes}

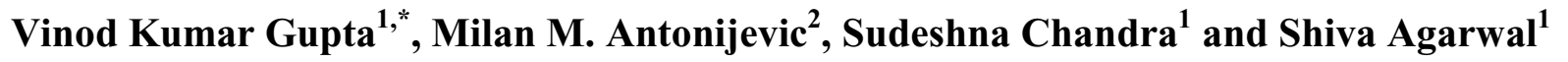 \\ ${ }^{1}$ Department of Chemistry, Indian Institute of Technology Roorkee (formerly University of Roorkee), \\ Roorkee- 247667 (India). Tel: 0091-1332-85801. Fax: 0091-1332-73650. \\ ${ }^{2}$ Department of Chemistry and Chemical Technology, Technical Faculty Bor, University of Belgrade, \\ P.O.Box 50, 19210 Bor, Serbia, Yugoslavia \\ * Author to whom correspondence should be addressed. E-mail: vinodfcy@,iitr.ernet.in
}

Received: 2 June 2002 / Accepted: 18 June 2002 / Published: 24 June 2002

\begin{abstract}
Silver(I) selective sensors have been fabricated from polystyrene matrix membranes containing macrocycle, $\mathrm{Me}_{6}(14)$ diene. $2 \mathrm{HClO}_{4}$ as ionophore. Best performance was exhibited by the membrane having a composition macrocycle : Polystyrene in the ratio 15:1. This membrane worked well over a wide concentration range $5.0 \times 10^{-6}-1.0 \times 10^{-1} \mathrm{M}$ of $\mathrm{Ag}^{+}$with a near-Nernstian slope of $53.0 \pm 1.0 \mathrm{mV}$ per decade of $\mathrm{Ag}^{+}$activity. The response time of the sensor is $<15 \mathrm{~s}$ and the membrane can be used over a period of four months with good reproducibility. The proposed electrode works well in a wide $\mathrm{pH}$ range 2.5-9.0 and demonstrates good discriminating power over a number of mono-, di-, and trivalent cations. The sensor has also been used as an indicator electrode in the potentiometric titration of silver(II) ions against $\mathrm{NaCl}$ solution. The sensor can also be used in non-aqueous medium with no significant change in the value of slope or working concentration range for the estimation of $\mathrm{Ag}^{+}$in solution having up to $25 \%(\mathrm{v} / \mathrm{v})$ nonaqueous fraction.
\end{abstract}

Keywords: Ion-selective electrodes, Sensors, $\mathrm{Ag}^{+}$-selective electrode, $\mathrm{Me}_{6}(14)$ diene. $2 \mathrm{HClO}_{4}$

\section{Introduction}

The determination of heavy metal ions in water, soil, and effluents is important in view of their toxic nature above certain concentration level. Elevated environmental level of heavy metals come from a variety of sources. The average crustal abundance of silver has been estimated at $0.07 \mathrm{mg} / \mathrm{kg}$, 
ranking it $69^{\text {th }}$ amongst the element. Silver is thus less common than metals such as cadmium and mercury but more abundant than selenium, gold or platinum. Bulk of silver produced in the world is used in photographic materials. Other major uses of silver are in the manufacture of sterling and plated ware, jewellery, coins, medallions, electrical and electronic products such as batteries, contacts and conductors, brazing alloys and solders, catalysts, mirrors and dental and medical supplies. Whereas silver has a relatively low toxicity to humans and other highest life forms, to primitive life forms such as bacteria and viruses, silver is as toxic as the most powerful chemical disinfectant. This gives the metal great potential as disinfectant. Silver nitrate taken orally caused necrosis of the gastrointestinal tract. In the body silver is precipitated by chloride ion or protein. Generalized argyria, localized argyria and argyrosis (argyria of the eye, unless otherwise stated) are the most common effects of chronic exposure to silver. Argyria occurred almost exclusively among silver nitrate makers and in some workers involved in mirror plating, silver mixing, photographic plate making and glass bead silvering, but it can also occur as a result of medicinal applications of silver.

Chemical sensors are increasingly used in the field of environmental analysis as they enjoy a number of advantages over other methods of analysis. The most attractive features of this technique are the speed with which samples can be analyzed, portability of the device, sample non-destruction, cost effectiveness and also large measuring range, often spanning across as many as six decades of ion concentration. Moreover, their fabrication in the laboratory is quite easy and may become commercially available soon after their development. During the last few decades efforts have been made by many researchers in the field of ISEs to develop sufficiently selective sensors for silver.

Unlike many other sulfide-based solid-state electrodes, the $\mathrm{Ag}_{2} \mathrm{~S}$ electrode has a very high primary ion selectivity and only weakly responds to most transition metal ions. Only $\mathrm{Hg}^{2+}$ gives a serious interference [1]. This may be one reason the interest is developing liquid membrane ISEs for $\mathrm{Ag}^{+}$has for a long time been fairly small. However, there have recently been an increasing number of reports on carrier- based $\mathrm{Ag}^{+}$selective electrodes [2]. These include membranes of crown ethers, viz., 1,4dithia-15-crown-5 and 1,4-dithia-12-crown-4 [3], dodecyl-16-crown-5 [4] and dibenzo-15-crown-4 [5]; calixarene based viz., thioether functionalized calix[4] arene [6]. Recently, Chen et al. [7] reported polymeric membranes based on two calix[4]arene derivatives functionalized by two hydroxy and two benzothiazoly-1-thioethoxy groups. These electrodes gave a Nernstian response in the activity range $5 \mu \mathrm{M}$ to $100 \mathrm{mM}$, a detection limit of $0.8 \mu \mathrm{M}$ and high selectivity towards alkali, alkaline earth and some transition metal ions. A loss in selectivity towards various metal ions is observed when an aromatic carbon in 2- position of benzene-1,3- bis(thioic) acid bis (S-propyl) ester is replaced by nitrogen atom [8]. Chung et al. [9] used sulfur containing podants with diisodecyl adipate in PVC matrix to develop $\mathrm{Ag}^{+}$selective sensor. Katsu and $\mathrm{Xu}$ [10] reported organoselenide as a noble ionophore for a silver selective membrane electrode. It gave a near-Nernstian response from $0.1 \mu \mathrm{M}$ to $0.01 \mathrm{M}$ with a slope of $52 \mathrm{mV}$ per decade of activity. Higher activities of silver ions are obtained with the selenides compounds than with the corresponding sulfides.

Taking into consideration all the above facts, $\mathrm{Me}_{6}(14)$ diene. $2 \mathrm{HClO}_{4}$ has been studied as an electroactive phase in polystyrene matrix for the fabrication of $\mathrm{Ag}^{+}$-selective electrode and the results are presented in this paper. The present electrode shows good selectivity over other cations and is superior to the existing electrodes in some aspects. 


\section{Experimental}

\section{Reagents}

All reagents used in the investigations were of analytical reagent grade (BDH, UK). Doubly distilled water was used for preparing all aqueous solutions.

Preparation of $\mathrm{Me}_{6}(14)$ diene. $2 \mathrm{HClO}_{4}$

$20 \mathrm{~g}$ of ethylenediamine was added to $500 \mathrm{ml}$ of anhydrous acetone followed by drop wise addition of $55.7 \mathrm{~g}$ of $60 \%$ perchloric acid from a dropping funnel with constant stirring of the solution. After addition of the acid, the solution was vigorously stirred and allowed to cool to room temperature. The fine crystalline compound was filtered and washed thoroughly with acetone and dried in vacuum. The ligand was a white crystalline material that can be recrystallised from hot aqueous methanol. This compound shows a strong broad band at $3050 \mathrm{~cm}^{-1}$ in the infrared spectra due to the $\mathrm{N}-\mathrm{H}$ vibration, and another weaker but broad band at $1530 \mathrm{~cm}^{-1}$ due to $\mathrm{NH}_{2}{ }^{+}$vibration. The $\mathrm{C}=\mathrm{N}$ stretching mode occurs as a strong sharp band at $1650 \mathrm{~cm}^{-1}$. The melting point of the ligand is $110^{\circ} \mathrm{C}$.

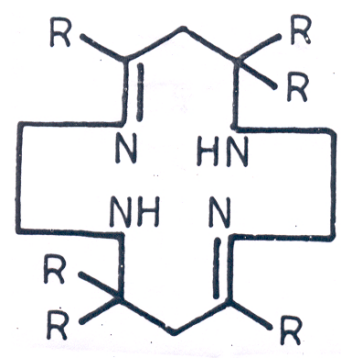

Apparatus

The potential measurements were carried out at $25 \pm 0.1^{\circ} \mathrm{C}$ on a $\mathrm{PH} 5652$ digital pH meter/millivoltmeter (ECIL, Hyderabad, India) and CVM 301 Century microvoltmeter (Century Instruments, Chandigarh, India). $\mathrm{pH}$ measurements were made on a digital $\mathrm{pH}$ meter ( model $\mathrm{PH} 5652$, ECIL, Hyderabad, India; Glass electrodes as pH electrode and calomel as reference electrode).

\section{Membrane preparation}

Heterogeneous membranes were prepared by taking different compositions of the ionophore and polystyrene and the mixture was heated to $80^{\circ} \mathrm{C}$ under pressure (6500 to $\left.7000 \mathrm{psi}\right)$ in a die kept in a metallurgical specimen mount press. Membranes were fabricated under optimum conditions of temperature and pressure which were fixed up after a great deal of preliminary investigations. Membranes prepared in this way were quite stable and did not show any dispersion in water or in other electrolyte solutions.

The membranes were subjected to microscopic and electrochemical examination for cracks and homogeneity of the surface and only those which had smooth surface and generated reproducible potentials were chosen for subsequent investigations. Membrane to membrane (and batch to batch) reproducibility was assured by carefully controlling the conditions of fabrication. 


\section{Determination of Functional Properties of Polystyrene based Membranes}

The prerequisite for understanding the performance of a membrane is its complete physicochemical characterization which involves the determination of all such parameters which affects its electrochemical properties. These parameters are porosity, electrolyte absorption, water content and swelling. A survey of literature reveals that this particular aspect of membrane phenomena has received less importance.

The first major attempt to establish standard methods for membrane characterization was reported on dried colloidal membrane by Michaelis [11]. Hale et.al. [12] investigated the effect of resin content and the degree of cross linking of the resin on the physical and electrochemical properties of membranes. Gregor [13] and Kawabe [14] studied the characterization of ion-exchange membrane in a number of different exchange states and correlated this information with their structure. Wyllie and Kannan [15] reported that if a rigid plastic such as polystyrene is used the properties of the ionexchange membrane may be modified. Lakshminarayaniah and Subhramaniyam [16] gave a direct method of measuring the membrane resistance which gives better results as compared to the methods followed by earlier workers. Another important parameter which plays an important role in the functioning of a membrane electrode is the surface study. A detailed methodology of surface study and its effect on the membrane was reported by Marco [17] in 1990.

\section{Porosity}

The stability, response time and selectivity of an electrode is influenced by the diameter and the multiplicity of the membrane pores. Mizutani and Nishimura [18] gave the method for the estimation of porosity of the membrane which is calculated from water content data by using the following formula:

$$
\Sigma=\text { water content/ A.L. } \rho_{\mathrm{w}}
$$

Where, $A=$ area of the membrane, $L=$ thickness and $\rho_{\mathrm{w}}=$ Density of water

\section{Electrolyte Absorption}

The membrane after attaining equilibrium in $1.0 \mathrm{M} \mathrm{NaCl}$ solution was wiped free of adhering electrolyte and then dipped in $20 \mathrm{~mL}$ distilled water. It was shaken intermittently and left as such foe few hours. The solution was then transferred to a $100 \mathrm{~mL}$ measuring flask, The whole process was repeated 3-4 times and the entire solution was collected in a measuring flask. It was finally made up to the mark by distilled water and the strength was measured conductometrically.

\section{Water Content}

Membrane was kept immersed in a solution of $1.0 \mathrm{M}$ concentration of electrolyte. It was then washed several times with distilled water and the adhering liquid was wiped off with blotting paper. Then the membrane was weighed and dried to a constant weight in a vacuum desiccator. The 
difference in the two weighings divided by the weight of the wet membrane was taken as the water content.

Swelling

After measuring the thickness of the dried membrane it was immersed into $1.0 \mathrm{M}$ solution of $\mathrm{NaCl}$ for 24 hours and again the thickness was measured after wiping with blotting paper. Difference between the thickness of dry and swollen membrane was taken as a measurement of swelling.

\section{Potential Measurements}

The membranes were equilibrated for 3 days in $1.0 \mathrm{M} \mathrm{Ag}^{+}$solution to generate noiseless and reproducible potentials. The conditions necessary for equilibration i.e., the contact time and concentration of salt solutions of the cation were decided by observing the performance of electrode systems equilibrated for different period of time with solutions of varying concentrations.

The membranes were fixed to one end of a "Pyrex" glass tube with araldite and equilibrated with silver nitrate solution. The glass tube containing $0.1 \mathrm{M}$ silver nitrate solution, as the internal solution, was placed in test solutions of different concentrations. Potentials were measured by direct potentiometry at $25 \pm 0.1^{\circ} \mathrm{C}$ with the help of ceramic junction calomel electrodes and the cell setup was the same as reported earlier [19]. $1.0 \times 10^{-1} \mathrm{M}$ silver nitrate was taken as inner reference solution and saturated calomel electrodes (SCE) were used as reference electrode. All pH adjustments were made with appropriate acid or base.

\section{Results and Discussion}

\section{Membrane Characteristics}

Functional properties of polystyrene based membrane no. 3 of macrocycle $\mathrm{Me}_{6}(14)$ diene. $2 \mathrm{HClO}_{4}$ are given in Table 1. Potential studies on the membrane sensors were carried out with the varying $\mathrm{Ag}^{+}$ concentration $\left(1.0 \times 10^{-6}\right.$ to $\left.1.0 \times 10^{-1} \mathrm{M}\right)$. Table 2 depicts the results of the working concentration range, slope, and response time of each membrane. The membranes with macrocycle and polystyrene in the ratio 8:1 showed a large response time with less Nernstian potential response and a narrow working concentration range. Though the membranes having macrocycle and polystyrene in the ratio 20:1 and 30:1 (w/w) showed a fast response time (20s) and near- Nernstian slope (40 mV/decade) each, respectively but they exhibited a narrow working concentration range. The membranes with macrocycle and polystyrene in the ratio $12: 1$ and 15:1 (w/w) showed a near- Nernstian slope with a response time of 20 and $15 \mathrm{~s}$ respectively. Membrane sensor no.3 exhibited a rectilinear potential response in the concentration range of $5.0 \times 10^{-6}-1.0 \times 10^{-1} \mathrm{M}$ with a near-Nernstian slope of 53 $\mathrm{mV} /$ decade of $\left[\mathrm{Ag}^{+}\right]$. Potentials generated with dummy membranes were insignificant $(5-10 \mathrm{mV})$. As such, the potentials generated in the proposed sensor are ascribed to the uptake of silver ions on the macrocycle. Thus, it can be seen that the membrane no. 3 (Fig.1a) gave the best performance with regard to working concentration range, slope and response time. The sensing behavior of the 
membranes did not change when the potentials were recorded from lower to higher concentrations or vice versa.

Table 1. Functional properties of polystyrene based membrane of macrocycle $\mathrm{Me}_{6}(14)$ diene. $2 \mathrm{HClO}_{4}$.

\begin{tabular}{|l|l|l|l|l|}
\hline $\begin{array}{l}\text { Membrane } \\
\text { No.3 }\end{array}$ & $\begin{array}{l}\text { Water content per gram of wet } \\
\text { membrane } \\
\mathbf{g}\left(\mathbf{H}_{\mathbf{2}} \mathbf{O}\right) / \mathbf{g}(\mathbf{w} . \mathbf{m e m} \text { ) } ; \mathbf{g} / \mathbf{g}\end{array}$ & Porosity & Swelling & $\begin{array}{l}\text { Amount of electrolyte } \\
\text { absorbed per gram of wet } \\
\text { membrane (moles) }\end{array}$ \\
\hline $\begin{array}{c}\mathrm{Me}_{6}(14) \text { diene. } \\
2 \mathrm{HClO}_{4}\end{array}$ & 0.0254 & 0.0320 & 0.204 & $4.6 \times 10^{-2}$ \\
\hline
\end{tabular}

Table 2. Composition of polystyrene based membranes of $\mathrm{Me}_{6}(14)$ diene. $2 \mathrm{HClO}_{4}$ and performance characteristics of $\mathrm{Ag}^{+}$- selective electrodes based on them.

\begin{tabular}{|c|c|c|c|c|c|}
\hline \multirow[b]{2}{*}{$\begin{array}{l}\text { Membrane } \\
\text { No. }\end{array}$} & \multicolumn{2}{|c|}{ Composition in ratio $(w / w)$} & \multirow[b]{2}{*}{$\begin{array}{l}\text { Working concentration } \\
\text { range, } M\end{array}$} & \multirow[b]{2}{*}{$\begin{array}{l}\text { Slope, } \\
\mathrm{mV} / \text { decade }\left[\mathrm{Ag}^{+}\right]\end{array}$} & \multirow{2}{*}{$\begin{array}{l}\text { Respon } \\
\text { se time, } \\
\text { s }\end{array}$} \\
\hline & $\begin{array}{l}\mathrm{Me}_{6}(14) \text { diene. } \\
\text { 2HClO }_{4} \text { (ionophore) }\end{array}$ & $\begin{array}{l}\begin{array}{l}\text { Polystyrene } \\
\text { (Binder) }\end{array} \\
\end{array}$ & & & \\
\hline 1 & 8 & 1 & $5.0 \times 10^{-5}-1.0 \times 10^{-1}$ & 48 & 30 \\
\hline 2 & 12 & 1 & $1.0 \times 10^{-5}-1.0 \times 10^{-1}$ & 53 & 20 \\
\hline 3 & 15 & 1 & $5.0 \times 10^{-6}-1.0 \times 10^{-1}$ & 53 & 15 \\
\hline 4 & 20 & 1 & $5.0 \times 10^{-5}-1.0 \times 10^{-1}$ & 40 & 20 \\
\hline 5 & 30 & 1 & $1.0 \times 10^{-4}-1.0 \times 10^{-1}$ & 40 & 20 \\
\hline
\end{tabular}

\section{Reference Solution}

In order to observe the effect of reference solution concentration on the functioning of the membrane sensor, measurements with varying concentrations with reference solutions $\left(5.0 \times 10^{-2}\right.$ and $1.0 \times 10^{-2} \mathrm{M} \mathrm{Ag}^{+}$solutions) were also observed (Fig 1b). It was found that the membrane sensor exhibited optimum performance at $1.0 \times 10^{-1} \mathrm{M}$ concentration of $\mathrm{Ag}^{+}$ions as internal solution while at other concentration the magnitude of potential falls and the working concentration range also decreased with decreasing concentration of reference solution. Therefore all subsequent investigations were performed with $1.0 \times 10^{-1} \mathrm{M}$ concentration of $\mathrm{Ag}^{+}$as reference solution.

\section{Response and Lifetime}

The static response time (time in which the membrane sensor generates constant potential) of the membrane sensor is observed at various determinand ion concentrations and the same is found to be $<15 \mathrm{~s}$ at all dilutions. Besides this, the potentials stayed constant for more than $3 \mathrm{~min}$, after which a slow divergence is recorded. Potentials were repeatedly monitored at a fixed concentrations and the standard deviation of twenty identical potential measurements is $0.2 \mathrm{mV}$. The membrane sensor could be used for four months, at a stretch, without observing any change in response time or slope, 
thereafter a slight change in slope and response time is observed and this could be corrected by equilibrating the membrane again with $1.0 \mathrm{M} \mathrm{Ag}^{+}$solution for $10 \mathrm{~h}$ (lesser time is required in comparison to the initial equilibration). With this treatment the assembly could again be used for two months time and then it was replaced by a fresh membrane.

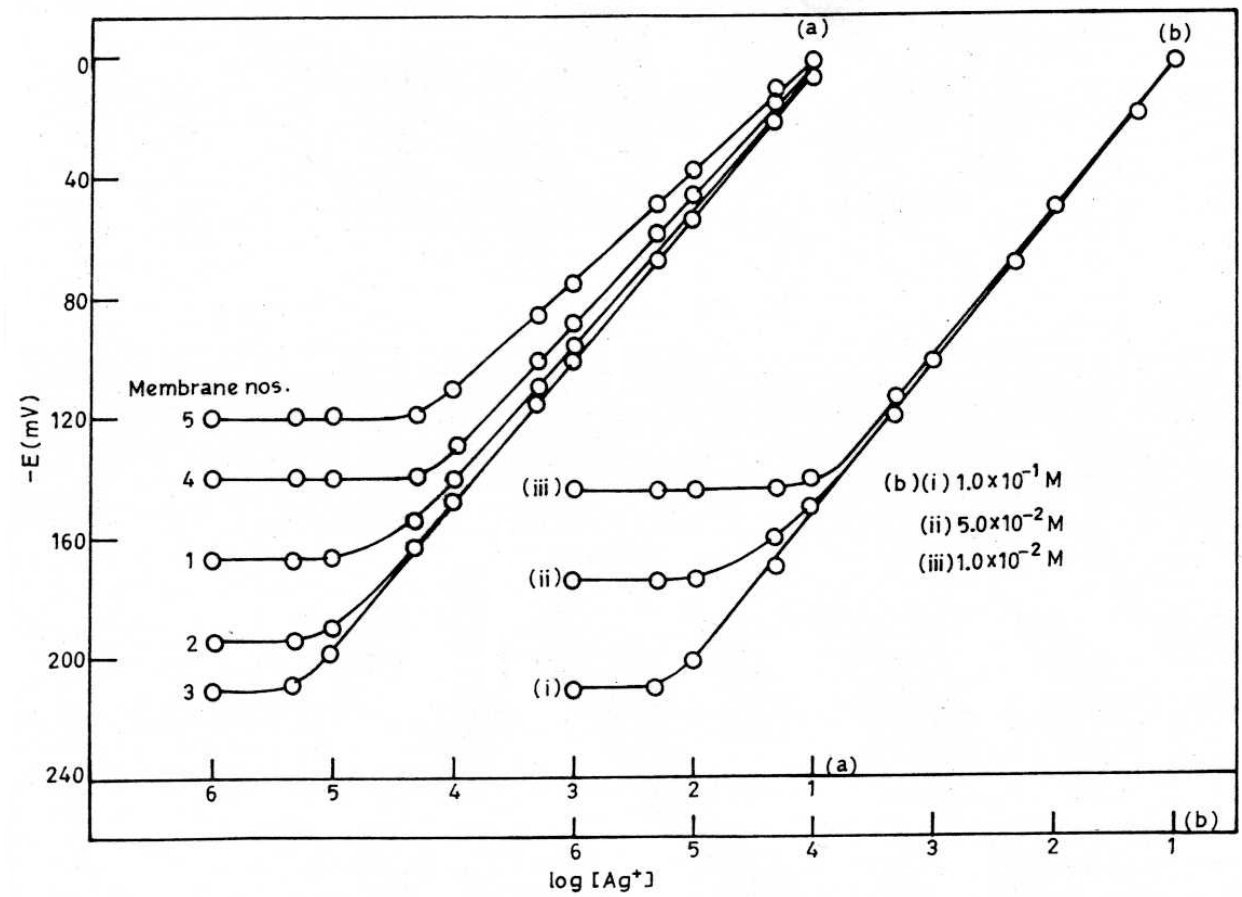

Figure 1. (a) Potential vs $-\log \left[\mathrm{Ag}^{+}\right]$plots of different compositions. (b) Potential vs $\log \left[\mathrm{Ag}^{+}\right]$plots of varying compositions of internal reference solutions.

\section{pH and Solvent Effect}

The potentiometric response of the silver electrode was found to be sensitive to $\mathrm{pH}$ changes. Thus, the $\mathrm{pH}$ dependence of the electrodes was tested by measuring the potential response of solutions containing $1.0 \times 10^{-3}$ and $1.0 \times 10^{-2} \mathrm{M}$ of silver ions in the $\mathrm{pH}$ range $1.0-11.0$. The $\mathrm{pH}$ was adjusted using nitric acid or ammonium hydroxide. As seen from Fig.2, the potential remained constant from 2.5 to 9.0 , which can be taken as the working $\mathrm{pH}$ range of the assembly. Beyond this $\mathrm{pH}$ range a drift in potentials was observed. The observed drift at higher $\mathrm{pH}$ values could be due to the formation of some hydroxy complexes of $\mathrm{Ag}^{+}$in solution. At low $\mathrm{pH}$, there could be protonation of the macrocycle in the membrane, which results in loss of their complexing ability with the metal ion.

The performance of the membrane (no. 3) was also investigated in partially non-aqueous medium using methanol-water, ethanol-water, and acetone-water mixtures. The membrane worked satisfactorily in solutions having maximum of $25 \%(\mathrm{v} / \mathrm{v})$ non-aqueous content as in these mixtures the working concentration range and slope remained unaffected (Fig.3). However, above 25\% nonaqueous content, slope, and working concentration range was reduced and potentials showed drift. It is worth mentioning that the lifetime of the membranes did not alter in non- aqueous solutions. 


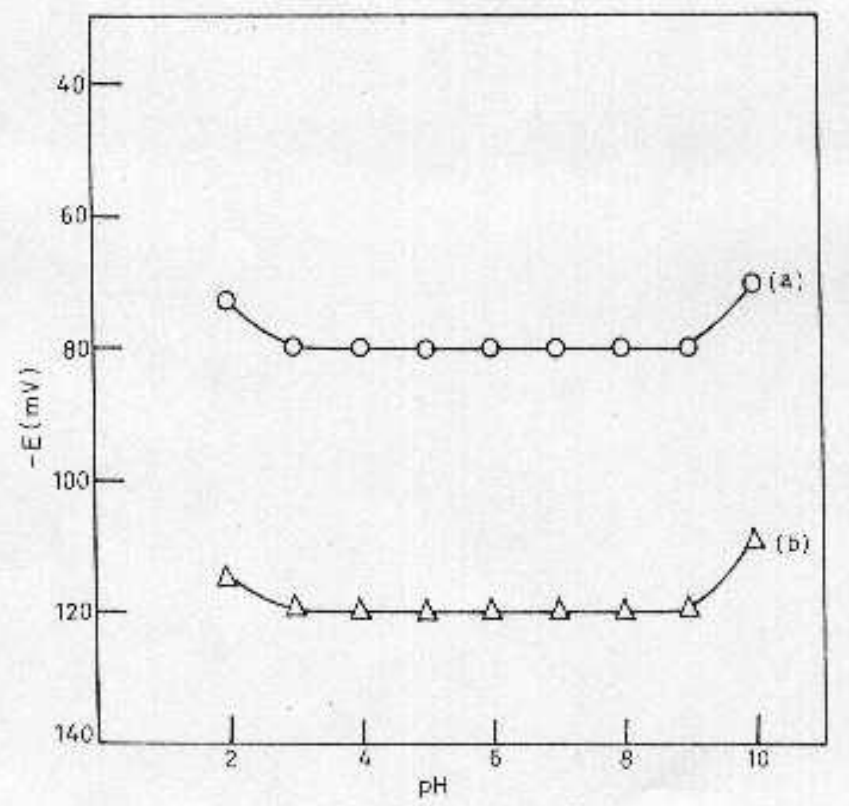

Figure 2. Effect of $\mathrm{pH}$ on cell potential; $\left[\mathrm{Ag}^{+}\right]=1.0 \times 10^{-2} \mathrm{M}(\mathrm{a})$ and $1.0 \times 10^{-3} \mathrm{M}(\mathrm{b})$.

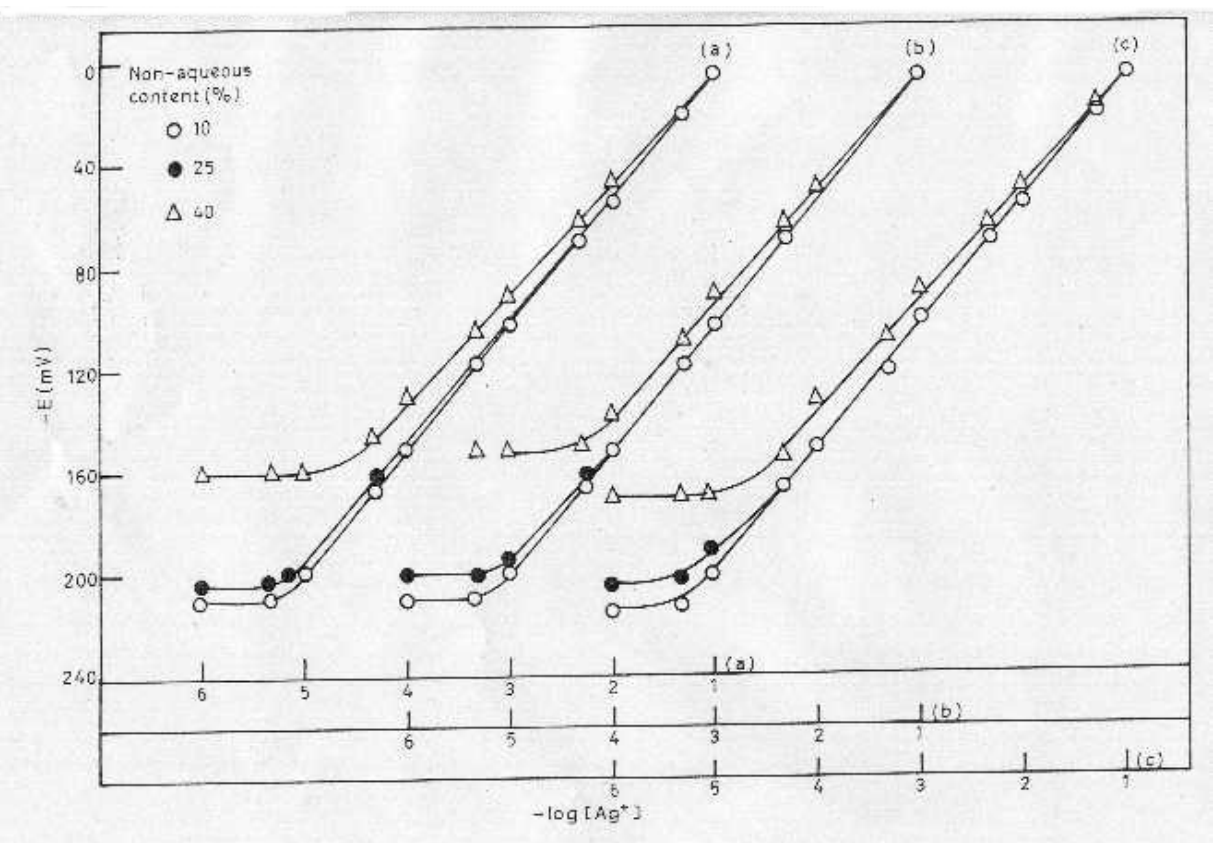

Figure 3. Variation of cell potential with $\mathrm{Ag}^{+}$concentration in (a) ethanol-water (b) methanol-water and (c) acetone-water mixtures.

\section{Potentiometric Selectivity}

The selectivity coefficients $\left(K_{A, B}^{P o t}\right.$ ) were evaluated by modified form of the fixed interference method [16] as suggested by Sa'ez de Viteri and Diamond at $1.0 \times 10^{-2} \mathrm{M}$ interfering ion concentration and varying concentration of $\mathrm{Ag}^{+}$solution (Table 3 ). The selectivity pattern indicates sufficiently low $\left(\sim 10^{-3}\right)$ values for monovalent cations and quite low $\left(\sim 10^{-4}\right)$ for bivalent and trivalent ions. As such, 
these cations are not expected to interfere even at this higher concentration level $\left(1.0 \times 10^{-2} \mathrm{M}\right)$ of the interfering ions. Heavy metals such as $\mathrm{Cu}^{2+}, \mathrm{Cd}^{2+}, \mathrm{Hg}^{2+}$ and $\mathrm{Pb}^{2+}$ ( normal interferents) also do not disturb the functioning of the membrane sensor at all.

Table 3. The selectivity coefficient values $\left(K_{A g^{+}, B}^{P o t}\right)$ for $\mathrm{Ag}^{+}$selective sensor as calculated by fixed interference method

\begin{tabular}{|c|c|}
\hline Interfering ion (B) & $\begin{array}{c}\text { Selectivity coefficients by Fixed interference } \\
\text { method }\end{array}$ \\
\hline $\mathrm{NH}_{4}^{+}$ & $4.46 \times 10^{-3}$ \\
\hline $\mathrm{Na}^{+}$ & $3.16 \times 10^{-3}$ \\
\hline $\mathrm{K}^{+}$ & $4.46 \times 10^{-3}$ \\
\hline $\mathrm{Li}^{+}$ & $5.0 \times 10^{-3}$ \\
\hline $\mathrm{Mg}^{2+}$ & $5.0 \times 10^{-4}$ \\
\hline $\mathrm{Ca}^{2+}$ & $3.54 \times 10^{-4}$ \\
\hline $\mathrm{Sr}^{2+}$ & $3.54 \times 10^{-4}$ \\
\hline $\mathrm{Ba}^{2+}$ & $5.0 \times 10^{-4}$ \\
\hline $\mathrm{Cu}^{2+}$ & $3.54 \times 10^{-4}$ \\
\hline $\mathrm{Cd}^{2+}$ & $2.52 \times 10^{-4}$ \\
\hline $\mathrm{Co}^{2+}$ & $3.54 \times 10^{-4}$ \\
\hline $\mathrm{Pb}^{2+}$ & $3.16 \times 10^{-4}$ \\
\hline $\mathrm{Hg}^{2+}$ & $4.46 \times 10^{-4}$ \\
\hline $\mathrm{Ni}^{2+}$ & $3.54 \times 10^{-4}$ \\
\hline $\mathrm{Al}^{3+}$ & $1.16 \times 10^{-4}$ \\
\hline $\mathrm{Cr}^{3+}$ & $2.32 \times 10^{-4}$ \\
\hline $\mathrm{Fe}^{3+}$ & $1.32 \times 10^{-4}$ \\
\hline
\end{tabular}

\section{Analytical Application}

The practical applicability of the electrode was tested by using it as an indicator electrode to determine the end point in the potentiometric titration of $\mathrm{Ag}^{+}$with $\mathrm{NaCl}$ solution. $20 \mathrm{~mL}$ of $1.0 \times 10^{-3}$ $\mathrm{Ag}^{+}$solution was titrated against $4.0 \mathrm{~mL}$ of $1.0 \times 10^{-3} \mathrm{M} \mathrm{NaCl}$ solution. The potential data are plotted against the volume of $\mathrm{NaCl}$ (Fig. 4). Although the changes observed in potentials are not large, the end point is quite sharp and a perfect stoichiometry is observed. The removal of silver ions results in a decrease in membrane potentials and beyond the end point the potentials almost stay constant and the change is also nominal. 


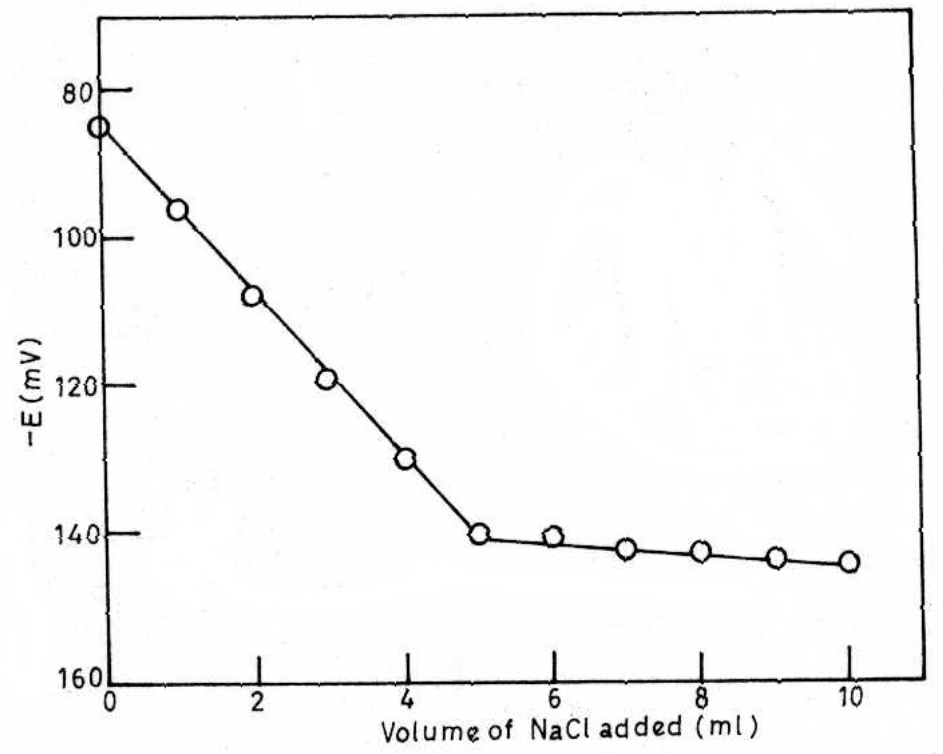

Figure 4. Plot of potentiometric titration of $20 \mathrm{~mL}$ of $1.0 \times 10^{-3} \mathrm{M} \mathrm{Ag}^{+}$against $4.0 \times 10^{-3} \mathrm{M}$ $\mathrm{NaCl}$ solution.

\section{Conclusion}

The polystyrene based membrane incorporating $\mathrm{Me}_{6}(14)$ diene. $2 \mathrm{HClO}_{4}$ as an ionophore, could be used to determine $\mathrm{Ag}^{+}$in the concentration range $5.0 \times 10^{-6}-1.0 \times 10^{-1} \mathrm{M}$ with a slope of 53.0 $\mathrm{mV} /$ decade of activity. The sensor works in a wide $\mathrm{pH}$ range $2.5-9.0$ with a response time of $15 \mathrm{~s}$. The selectivity of the electrode towards $\mathrm{Ag}^{+}$is quite good over other cations and the lifetime of the assembly is 4 months in aqueous and non-aqueous medium also. In addition, the membrane sensor can be used as an indicator electrode in potentiometric titration involving silver(I) ions against $\mathrm{NaCl}$.

\section{Acknowledgement}

The authors are highly thankful to Council of Scientific and Industrial Research (CSIR), New Delhi, India for providing financial help.

\section{References}

1. Umezawa, Y. CRC Handbook of Ion Selective Electrodes: Selectivity Coefficients. CRC Press: Boca Raton, Ann Arbor, Boston, (1990).

2. Casabo, J.; Teixidor, F.; Escriche, L.; Vinas, C.; Perez- Jimenez, C. Adv. Mater.1995, 7, 238 .

3. Lai, M. T.; Shia, J. S. Analyst. 1986, 111, 891.

4. Oue, M.; Kimura, K.; Akama, K.; Tanaka, M.; Shono, T. Chem. Lett. 1988, 3, 409.

5. Xi, Z.; Li, J.; Yu, L.; Zhang, D.; Yang, J.; Luo, S.; Wu, B.; Cun, L. Huaxue Xuebao 1986, 44, 951. 
6. Malinowska, E.; Brazozka, Z.; Kasiura, K.; Egberink, R.J.M.; Reinhoudt, D.N. Anal. Chi. Acta. 1994, 298, 245.

7. Chen, L.X.; Zeng, X.S.; He, X.M.; Zhang, Z.Z. Frensenius' J. Anal. Chem. 2000, 367, 535.

8. Bates, M.; Cardwell, T.J.; Cattrall, R.W.; Deady, L.W.; Gregorio, C. G. Talanta 1995, 42, 999.

9. Chung, S.; Kim, W.; Park, S. B.; Kim, O.Y.; Lee, S. S. Talanta 1997, 44, 1087.

10. Katsu, T.; Xu, D. H. Anal. Lett. 1998, 31, 1979.

11. Michaelis, L. Proc. Intern. Congr. Plant Sci. Itlaco 1929, 2, 1139.

12. Hale, D.K.; McCanley, M.J. Trans. Faraday. Soc. 1961, 57, 135.

13. Gregor, H.P.; Jacobson, H.; Shir, R. C. J. Phy. Chem. 1957, 61, 141.

14. Kawabe, M.; Tanagita, M.; Shinohara, M.; Takamatsu, T. Bull. Chem. Soc. Jpn. 1962, 21, 157.

15. Wyllie, M. R. J.; Kannan, S. L. J. Phy. Chem. 1954, 58, 73.

16. Lakshminarayaniah, N.; Subrahmanayam, V. J. Phy. Chem. 1968, 72, 4314.

17. Marco, R.D.; Cattrall, R.W.; Leisengang, J. Anal. Chem. 1990, 62, 2339.

18. Mizutani, V.; Nishimura, M. J. Appl. Polymer Sci. 1970, 14, 1847.

19. Srivastava, S. K.; Gupta, V. K.; Dwivedi, M. K.; Jain, S. Anal. Proc. 1995, 32, 21.

Sample Availability: Available from the authors.

(C) 2002 by MDPI (http://www.mdpi.net). Reproduction is permitted for noncommercial purposes. 